\title{
The Production by Certain Species of Clostridium of Enzymes Disintegrating Hide Powder
}

\author{
BY D. G. EVANS \\ National Institute for Medical Research, Hampstead, London
}

SUMMARY: The production by certain species of Clostridium of enzymes disintegrating hide powder was investigated by measuring the lytic action of broth cultures and toxic filtrates on finely divided hide powder suspended in an agar gel.

$\mathrm{Cl}$. histolyticum was the most active producer of enzyme, $\mathrm{Cl}$. welchii $\mathrm{A}$ was less active and $\mathrm{Cl}$. sporogenes and $\mathrm{Cl}$. bifermentans only moderately active. $\mathrm{Cl}$. tetani, $\mathrm{Cl}$. oedematiens and $\mathrm{Cl}$. septicum produced no such enzyme. The lytic enzyme of $\mathrm{Cl}$. histolyticum is not the lethal toxin.

Among strains of $\mathrm{Cl}$. welchii type A, enzyme production, $x$-toxin production and ability to cause fatal infection in guinea-pigs are associated.

There was some evidence that the different enzymes affecting hide powder are antigenically related, but no definite conclusion is possible, since the antisera employed may have contained antibodies to the lytic enzymes of a number of different organisms.

Maschmann (1938) claimed that $\mathrm{Cl}$. welchii elaborated an enzyme which splits collagen. This he named collagenase but recorded no experiments demonstrating its specific action. Later Jennison (1945) recorded the disintegration of collagen fibres by enzymes produced in actively growing cultures of aerobic and anaerobic organisms. Macfarlane \& MacLennan (1945), confining their study to $\mathrm{Cl}$. welchii Type $\mathbf{A}$, found that culture filtrates were able to break down muscle by their action on the collagen of the reticulin scaffolding. They regarded the active substance as a collagenase and suggested that it was responsible for the muscle destruction observed in cases of gas gangrene caused by $\mathrm{Cl}$. welchii $\mathrm{A}$ and thus played an important part in the pathogenesis of the disease. The collagenase of $C l$. welchii A was shown by Oakley, Warrack \& van Heyningen (1946) to be immunologically distinct from the other known antigens present in culture filtrates, and $\mathrm{Cl}$. welchii $\mathrm{A}$ antisera contained a distinct anticollagenase. Evans $(1945 b, 1947)$ showed that the anticollagenase alone had no protective action in experimental $\mathrm{Cl}$. welchii $\mathrm{A}$ infections, and concluded that although collagenase may be responsible for the muscle destruction observed in $\mathrm{Cl}$. welchii $\mathrm{A}$ infections, there was no evidence to suggest that it had any significant role in determining whether fatal infection would follow the injection of a given inoculum of $\mathrm{Cl}$. welchii $\mathbf{A}$.

The strains of $\mathrm{Cl}$. welchii A used in these experimental infections all produced collagenase in vitro, though in variable amounts. Oakley et al. (1946), in estimating the anticollagenase potency of $\mathrm{Cl}$. welchii antisera, obtained identical results using as substrate either collagen prepared from horse tendon or commercial hide powder. Hide powder, although not a pure substrate, is a rich and convenient source of collagen and was employed in the tests described below. The disintegration of hide powder, however, is not a specific 
indication of collagenase action but provides reasonable presumptive evidence that a collagenase is present. A study has been made of the in vitro production by a number of strains of $\mathrm{Cl}$. welchii $\mathrm{A}$ and by other species of Clostridium, of enzymes with ability to disintegrate hide powder.

\section{METHODS}

The production of lytic enzymes by $C l$. relchii $\mathbf{A}$ was first demonstrated by incorporating the hide powder in the culture medium. Hide powder was passed through a sieve, 60 meshes to the inch, dried over $\mathrm{P}_{2} \mathrm{O}_{5}$ in vacuo for 2 days and sterilized by dry heat at $100^{\circ}$ for $1 \mathrm{hr}$. To $100 \mathrm{ml}$. of saline $4 \mathrm{~g}$. of the hide-powder preparation were added and a smooth suspension obtained by vigorous agitation. This was added to melted Fildes's agar medium, $12 \%$ by volume, and pour-plates made in which the hide-powder particles were distributed densely and uniformly. Sterilization of the hide powder was necessary to eliminate contaminants, but it is improbable that the dry heating caused significant degradation of the collagen, for similar results were obtained with unsterilized hide powder.

After 24 hr. anaerobic growth on this medium strains of $\mathrm{Cl}$. welchii A gave colonies surrounded by a zone in which complete dissolution of the hide powder had occurred and which increased in size after a further $\mathbf{2 4} \mathrm{hr}$. incubation. With different strains the size of the zone of clearing varied from a faint nariuw zone to one three times the diameter of the colony.

The method was, however, unsuitable for comparing the lytic enzyme production of different strains of $\mathrm{Cl}$. welchii $\mathrm{A}$, or for detecting lysis by species of Clostridium that grow in widely spreading colonies. To obviate these difficulties, the amount of enzyme produced in broth cultures was titrated in cups cut in non-nutrient hide powder-agar plates. These plates were made by adding $2 \mathrm{ml}$. of the saline hide-powder suspension to $15 \mathrm{ml}$. of melted $4 \%$ agar in saline and pouring the mixture into a Petri dish. Cups of $7 \mathrm{~mm}$. diameter were cut with a cork-borer, and the amount of enzyme in a culture was then titrated by pipetting into each cup approximately $0.1 \mathrm{ml}$. of falling dilutions of an $18 \mathrm{hr}$. culture in rabbit-liver broth and incubating aerobically at $37^{\circ}$. After $24 \mathrm{hr}$, actively lytic strains gave around the cup a distinct concentric zone completely free from hide-powder particles; the zone increased in size after a further $24 \mathrm{hr}$. incubation, when the final readings were made. There was no disadvantage in filling the cups with whole-broth culture, since there was no possibility of the growth of anaerobes occurring on this medium. Moreover, tests made with the clear supernatant fluid from centrifuged cultures gave results identical with those using whole culture.

\section{RESULTS}

Lysis of hide powder by Clostridium welchii $A$

All the thirty strains of $\mathrm{Cl}$. welchii $\mathrm{A}$ which were used in a previous investigation (Evans, 1945a), and which had been preserved in the dry state in the meantime, were found to produce enzymes disintegrating hide powder. The 
zone of clearing was $25 \mathrm{~mm}$. in diameter with the most active strains and less than $10 \mathrm{~mm}$. in diameter with the least active. The strains were classified into three groups according to the diameter of the zone and arranged in order of $\alpha$-toxin production (Table 1 ). Strongly lytic cultures were active when diluted $1: 100$, but those which gave small zones were inactive when diluted $1: 4$ and in some cases $1: 2$. When enzyme production by the thirty strains of $\mathrm{Cl}$. welchii $\mathrm{A}$ is compared (Table 1) with $\alpha$-toxin production and the ability to cause fatal infection in guinea-pigs (Evans, 1945a), it is evident that there is a general association between these three properties.

Table 1. Comparison of hide-powder enzyme production with other properties of thirty strains of Clostridium welchii $A$

Enzyme production: $t=<10 \mathrm{~mm}$., $t+=10-15 \mathrm{~mm}$, and $t+t=>15 \mathrm{~mm}$. zone of hide-powder clearing.

$\alpha$-toxin production: figures $=$ number of units of $\alpha$-antitoxin required to neutralize the $\alpha$-toxin in $1 \mathrm{ml}$. of culture.

Virulence for guinea-pigs : $+=$ virulent; $-=$ avirulent.

\begin{tabular}{|c|c|c|c|}
\hline \multicolumn{3}{|c|}{ In vitro production of } & \multirow[b]{2}{*}{$\begin{array}{l}\text { Virulence for } \\
\text { guinea-pigs }\end{array}$} \\
\hline Strain & $\begin{array}{l}\text { Hide-powder } \\
\text { enzyme }\end{array}$ & $\alpha$-toxin & \\
\hline S107 & $+t+$ & $1 \cdot 60$ & + \\
\hline SR 12 & ++ & 0.95 & + \\
\hline A 119 & $+t+$ & 0.85 & + \\
\hline A 117 & $+t+$ & 0.60 & + \\
\hline A 118 & $+t+$ & $0 \cdot 60$ & + \\
\hline SR9 & $+t+$ & $0 \cdot 35$ & + \\
\hline Rosher & $+t+$ & 0.25 & + \\
\hline G5g & $+t+$ & $0 \cdot 25$ & + \\
\hline 3893 & +++ & $0 \cdot 20$ & + \\
\hline $\mathrm{S} 1 a$ & ++ & $0 \cdot 20$ & + \\
\hline BB & $+t+$ & $0 \cdot 20$ & + \\
\hline BS 1 & $+t+$ & $0 \cdot 20$ & + \\
\hline 3895 & ++ & $0 \cdot 15$ & - \\
\hline 26 & $+t+$ & $0 \cdot 15$ & + \\
\hline A 102 & + & $0 \cdot 15$ & - \\
\hline 274 & ++ & $0 \cdot 10$ & + \\
\hline Mills & ++ & $0 \cdot 10$ & + \\
\hline 7731 & ++ & $0 \cdot 10$ & + \\
\hline A 19 & ++ & $0 \cdot 10$ & + \\
\hline PL & + & 0.05 & $\dot{t}$ \\
\hline 5053 & ++ & 0.05 & + \\
\hline 529 & ++ & 0.03 & - \\
\hline P5706 & + & 0.03 & - \\
\hline Corcoran & $+t$ & 0.03 & - \\
\hline D5 & ++ & 0.03 & - \\
\hline 4226 & + & 0.02 & - \\
\hline A78b & + & 0.02 & - \\
\hline A $38 b$ & + & 0.02 & - \\
\hline D $3 a$ & + & 0.02 & - \\
\hline $\mathrm{A} 13 b$ & + & 0.02 & - \\
\hline
\end{tabular}

The zones of hide powder clearing were evidently produced by a true collagenase, since the activity of the cultures was neutralized by three of Dr Oakley's $\mathrm{Cl}$. welchii A antisera in proportion to their anticollagenase 
content. (1) Serum R5434 contained 50 units (Oakley, et al. 1946) of anticollagenase and $0 \cdot 2$ unit of $\alpha$-antitoxin per ml., (2) serum $\mathrm{R} 6423$ contained 75 units of $\alpha$-antitoxin per ml. but no detectable anticollagenase, and (3) serum Ex 1055 contained 2500 units of anticollagenase and 500 units of $\alpha$-antitoxin per ml. With each of the thirty strains of $\mathrm{Cl}$. welchii $\mathbf{A}$, mixtures of equal parts of an $18 \mathrm{hr}$. culture and each serum were held for $1 \mathrm{hr}$. at room temperature and then pipetted into the hide powder-agar-cup plates, which were incubated at $37^{\circ}$ for $48 \mathrm{hr}$. Serum R6423 had no effect on the zones of clearing produced by each of the thirty strains; the zones were similar in size to those produced by mixtures of culture and normal horse serum. On the other hand, serum R5434 completely inhibited the clearing produced by twenty-one of the strains; the remaining nine strains, all of which produced large zones, were partly neutralized, $20 \mathrm{~mm}$. zones being reduced to less than $12 \mathrm{~mm}$. in diameter. The more potent anticollagenase serum Ex 1055 completely neutralized the clearing by all thirty strains.

\section{Lysis of hide powder by other species of Clostridium}

The following strains were tested for enzyme production: $\mathrm{Cl}$. sporogenes: M1 $f$, M 41 a, M3g, M5 $f$; Cl. oedematiens: H1, Jolly, M131o, M4t; Cl. bifermentans: M74, M16, M15h, M58e, M1e; Cl. septicum: VS189, VS54, M16m, M40f; Cl. tetani: T67, T279; Cl. histolyticum: CN1693, CN950, CN919, CN920, CN949; and a non-pathogenic Clostridium with morphological and biochemical properties almost identical with those of $\mathrm{Cl}$. histolyticum but which did not produce histolyticum toxin: strains M37e, M55, M17l.

The M strains were isolated from war wounds by Mrs E. M. Miles, and the Cl. histolyticum strains were supplied by Miss Helen E. Ross of the Wellcome Physiological Research Laboratories. The strains had been preserved either in alkaline-egg medium or in the dry state, and were subcultured a number of times to bring them into an actively growing condition. For the titration of enzyme each strain was grown in rabbit-liver broth for 18-20 hr.

Cultures of all the $\mathrm{Cl}$. histolyticum strains produced rapid and complete dissolution of hide powder; even after $3 \mathrm{hr}$. a distinct rim of clearing was visible around the cups and at $24 \mathrm{hr}$. the diameter of the zone was $20 \mathrm{~mm}$., increasing to an average of $30 \mathrm{~mm}$. after a further $24 \mathrm{hr}$. incubation. The titres of these cultures were as high as 1:250. Each of the five strains of $\mathrm{Cl}$. histolyticum produced, in guinea-pigs, an infection showing extensive muscle destruction which, with the infecting doses employed, was not always accompanied by the death of the animal.

Cultures of $\mathrm{Cl}$. bifermentans, $\mathrm{Cl}$. sporogenes and the three $\mathrm{Cl}$. histolyticum-like strains also contained enzymes disintegrating hide powder. Their behaviour, however, differed from that of $\mathrm{Cl}$. welchii $\mathrm{A}$ and $\mathrm{Cl}$. histolyticum cultures. Although the zones of clearing at $24 \mathrm{hr}$. were distinct and $\mathbf{1 5 - 2 0 ~} \mathrm{mm}$. in diameter, the clearing was only partial. Large numbers of unchanged hidepowder particles were visible within the zones, while other particles appeared to be only slightly affected. After a furt her $24 \mathrm{hr}$. incubation, the zones became completely clear, although they were not well defined. The concentration of 
enzyme in these cultures was not high, for dilutions of 1:32 had little or no activity. The low concentration may have been responsible for the slow dissolution of the hide powder, for a concentrated filtrate of $\mathrm{Cl}$. bifermentans culture produced in $\mathbf{2 4} \mathrm{hr}$. a zone completely free from hide-powder particles.

No enzyme attacking hide powder was demonstrable in the cultures of $\mathrm{Cl}$. oedematiens, $\mathrm{Cl}$. septicum and $\mathrm{Cl}$.tetani. Two strains of each species proved to be highly pathogenic for guinea-pigs, so that with these organisms at least, virulence and enzyme production are not associated.

Some of Jennison's (1945) results have been confirmed in this investigation. $\mathrm{He}$ found that cultures of $\mathrm{Cl}$. histolyticum, $\mathrm{Cl}$. sporogenes and $\mathrm{Cl}$. bifermentans disintegrated collagen fibres and that $\mathrm{Cl}$. histolyticum was the most active. $\mathrm{He}$ reported, however, that $\mathrm{Cl}$. welchii did not affect the collagen substrate, a result which may well have been due to poor collagenase production by the strains of Cl. welchii he used.

\section{Lysis of hide powder by toxic filtrates}

A number of dry preparations of ammonium sulphate precipitates from toxic filtrates of various organisms of the gas gangrene group, were tested by the cup-plate method for enzyme activity. Forty mg. of each toxin were dissolved in $1 \mathrm{ml}$. of saline, giving solutions containing many mouse lethal doses $/ \mathrm{ml}$. The toxic precipitates from $\mathrm{Cl}$. tetani, $\mathrm{Cl}$. oedematiens and $\mathrm{Cl}$. septicum contained no enzyme which disintegrated hide powder, whereas those of $\mathrm{Cl}$. histolyticum and $\mathrm{Cl}$. welchii A produced clear wide zones in less than $24 \mathrm{hr}$. By titration it was found that the smallest concentration of toxin showing enzyme activity (M.E.D.) was $0.5 \mathrm{mg}$. $/ \mathrm{ml}$. with the most potent $C l$. welchii $\mathrm{A}$ preparation and $\mathbf{0 . 0 0 4} \mathrm{mg} . / \mathrm{ml}$. with the most potent $\mathrm{Cl}$. histolyticum toxin.

Five different dry ammonium sulphate precipitates, prepared from $\mathrm{Cl}$. histolyticum $(\mathbf{I}-\mathbf{V})$ in different institutes throughout the world, were titrated in parallel for enzyme activity and lethal power on intravenous injection in mice (Table 2). It is evident from the inconsistent ratios of enzyme activity to toxicity that the factors responsible for these two effects are not the same.

Table 2. Hide-powder enzyme activity and toxicity of Clostridium histolyticum toxins

$\begin{array}{cccc}\begin{array}{c}\text { Minimal enzyme } \\ \text { concentration } \\ \text { toxin sample }\end{array} & \begin{array}{c}\text { Minimal lethal } \\ \text { dose for mice }\end{array} & \begin{array}{c}\text { Ratio } \\ \text { (mg./ml.) }\end{array} & \begin{array}{c}\text { (mg.) } \\ \text { M.E.D. : M.L.D. }\end{array} \\ \text { I } & 1 / 256 & 1 / 32 & 8: 1 \\ \text { II } & 1 / 16 & 1 / 32 & 1: 2 \\ \text { III } & 1 / 128 & 1 / 8 & 16: 1 \\ \text { IV } & 1 / 64 & 1 / 16 & 4: 1 \\ \text { V } & 1 / 128 & 1 / 8 & 16: 1\end{array}$

\section{Neutralization of enzyme by antisera}

The cup-plate method was also used in an attempt to investigate the antigenic relationships of the enzymes attacking hide powder produced by the different organisms. Three antisera were employed : (1) Cl. welchii A horse anti- 
toxin Ex 1055, (2) the International Standard Cl. histolyticum antitoxin reconstituted so that 280 units of antitoxin were contained in $1 \mathrm{ml}$.; this antiserum was also from a horse, and (3) Cl. bifermentans rabbit antiserum 2718 (Miles \& Miles, 1947). Each serum was titrated for neutralization property with a number of homologous and heterologous enzyme preparations. Twofold dilutions of antiserum were made, and to each dilution an equal volume of the enzyme preparation was added. In most tests the mixtures were so constituted that the concentration of enzyme in each cup was eight times the smallest concentration which gave a reaction (8 M.E.D.). It was, however, necessary in some cases, where neutralization was only slight, to diminish the concentration of enzyme in the cup in order to obtain an end-point in the titration.

\section{Table 3. Neutralization of hide-powder enzyme by various antisera}

The figures indicate the reciprocal of the serum dilution, and the figures in brackets the number of minimal enzyme doses (H.E.D.) used in the titration.

\begin{tabular}{|c|c|c|c|c|}
\hline & & \multicolumn{3}{|c|}{ Neutralization titres of antisera } \\
\hline \multicolumn{2}{|c|}{ Enzyme preparation } & $\begin{array}{c}\text { welchii } \\
(\mathrm{Ex} 1055)\end{array}$ & $\begin{array}{l}\text { histolyticum } \\
\text { (Int. St.) }\end{array}$ & $\begin{array}{c}\text { bifermentans } \\
(2718)\end{array}$ \\
\hline Cl. roelchii: & $\begin{array}{l}\text { Toxin Welchpool } \\
\text { Culture Rosher }\end{array}$ & $\begin{array}{l}2048(8) \\
2048(8)\end{array}$ & $\begin{array}{l}32(8) \\
32(8)\end{array}$ & $\begin{array}{l}<2(2) \\
<2(2)\end{array}$ \\
\hline Cl. histolyticum: & $\begin{array}{l}\text { Toxin I } \\
\text { Toxin II } \\
\text { Culture CN920 } \\
\text { Culture CN } 1693\end{array}$ & $\begin{array}{l}2(4) \\
2(4) \\
2(4) \\
2(4)\end{array}$ & $\begin{array}{r}512(8) \\
1024(8) \\
512(8) \\
512(8)\end{array}$ & $\begin{array}{l}<2(2) \\
<2(2) \\
<2(2) \\
<2(2)\end{array}$ \\
\hline Cl. bifermentans: & $\begin{array}{l}\text { Culture M58e } \\
\text { Culture M15h }\end{array}$ & $\begin{array}{l}64(8) \\
32(8)\end{array}$ & $\begin{array}{l}32(8) \\
16(8)\end{array}$ & $\begin{array}{r}128(8) \\
64(8)\end{array}$ \\
\hline Cl. sporogenes: & $\begin{array}{l}\text { Culture M } 1 f \\
\text { Culture M } 5 f\end{array}$ & $\begin{array}{l}32(8) \\
32(8)\end{array}$ & $\begin{array}{l}8(8) \\
8(8)\end{array}$ & $\begin{array}{l}2(8) \\
4(8)\end{array}$ \\
\hline
\end{tabular}

Some evidence was obtained (Table 3) of an antigenic relationship between the enzymes of the different organisms. There were, however, inconsistencies in the results, such as the low titres of welchii antiserum with histolyticum antigens compared with the relatively higher titres of histolyticum antiserum with welchii antigens, and also the inability of the bifermentans antiserum to show cross-reactions with either zvelchii or histolyticum antigens, although both welchii and histolyticum antisera reacted with bifermentans enzyme. It was, of course, possible that the horse antisera contained antibodies to the lytic enzymes of a number of different organisms, naturally produced in the animals from which the sera were obtained. Nothing was known of the anti-enzymic properties of the sera of the animals before they were used for preparing the antisera, and there was evidence that the histolyticum serum came from a horse with some experience of $\mathrm{Cl}$. welchii A antigens. More was known of the bifermentans antiserum since it was prepared in a rabbit which had received only $\mathrm{Cl}$. bifermentans culture, and its greater specificity may have been a result of this, although, on the other hand, it may have been due to its low homologous titre. It is clear that if the antigenic relationship of the enzymes pro- 
duced by the different organisms were to be investigated, it would be necessary to prepare antisera in selected animals whose sera before immunization were entirely free from antibodies to enzymes disintegrating hide powder.

\section{DISCUSSION}

From the results of this investigation it may be stated that the ability of various species of Clostridium to elaborate enzymes affecting hide powder is not related to the pathogenicity of the species, for both pathogenic and nonpathogenic organisms produce enzymes which disintegrate hide powder and, furthermore, a number of pathogenic species of Clostridium show no such enzyme activity. It is noteworthy, however, that of the pathogenic organisms examined, $\mathrm{Cl}$. welchii $\mathrm{A}$ and $\mathrm{Cl}$. histolyticum, both of which elaborate the lytic enzyme, produce lesions with extensive muscle destruction, whereas muscle disintegration does not occur in lesions caused by $\mathrm{Cl}$. tetani, $\mathrm{Cl}$. oedematiens and Cl. septicum which do not produce the enzyme.

There is clearly an association between enzyme production and virulence of strains of $\mathrm{Cl}$. welchii $\mathrm{A}$, but so far there is no evidence to suggest that the ability to produce enzymes disintegrating hide powder in any way determines virulence, which appears to depend mainly on the production of the lethal $\alpha$-toxin (Evans, 1945b, 1947).

The part played by the antigens of $C l$. histolyticum in infections produced by this organism has not been so fully investigated, but $\mathrm{Cl}$. histolyticum produced in guinea-pigs a non-fatal infection with extensive muscle destruction. It is reasonable, therefore, to suppose that the enzyme disintegrating hide powder is associated with muscle destruction, and that when fatal infection occurs it is probably due to the lethal toxin of $\mathrm{Cl}$. histolyticum.

I am greatly indebted to Dr C. L. Oakley for supplies of $C l$. welchii A antisera and also to Miss Helen E. Ross and Mrs E. M. Miles for some of the strains.

\section{REFERENCES}

Evans, D. G. (1945a). The in vitro production of $\alpha$-toxin, $\theta$ haemolysin and hyaluronidase by strains of $\mathrm{Cl}$. welchii type $\mathrm{A}$, and the relationship of in vitro properties to virulence for guinea-pigs. J. Path. Bact. 57, 75.

Evans, D. G. (1945b). Gas gangrene. Lancet, ii, 478.

Evans, D. G. (1947). Anticollagenase in immunity to $\mathrm{Cl}$. welchii type A infection. Brit. J. exp. Path. 28, 24.

Jennison, M. W. (1945). Bacterial collagenase. J. Bact. 50, 369.

Macfarlane, R. G. \& Maclennan, J. D. (1945). The toxaemia of gas gangrene. Lancet, $2,328$.

Maschmann, E. (1938). Die Anaerobiase der Gasbranderreger. Biochem. Z. 297, 284.

Mrles, E. M. \& Miles, A. A. (1947). The lecithinase of Clostridium bifermentans and its relation to the alpha-toxin of Clostridium welchii. J. gen. Microbiol. 1, 385.

Oakley, C. L., Warrack, G. H. \& van Heyningen, W. E. (1946). The collagenase ( $\kappa$ toxin) of Cl. welchii type A. J. Path. Bact. 58, 229.

(Received 6 May 1947) 